\title{
United States - Countervailing Duties on Certain Corrosion-Resistant Carbon Steel Flat Products from Germany (WTO Doc. WT/DS213/AB/R): The Sounds of Silence*
}

\author{
BY \\ GENE M. GROSSMAN \\ Princeton University \\ AND \\ PETROS C. MAVROIDIS \\ University of Neuchâtel and Columbia University
}

\section{Facts of the Case}

On August 17, 1993, the United States Department of Commerce (USDOC) imposed definitive countervailing duties (CVDs) on carbon steel originating in Germany. The imposition of these duties was based on an investigation by USDOC in which it was determined that certain German producers had benefited from five countervailable subsidy programs at a total ad valorem rate of 0.60 percent.

On September 1, 1999, the USDOC gave notice of the automatic initiation of a sunset review of these duties, in accordance with Article 21.3 of the Agreement on Subsidies and Countervailing Measures (the SCM Agreement). ${ }^{1}$ The United States found, in the course of its review, that

* We are grateful to the ALI reporters and especially to Richard Baldwin, Bill Ethier, Bernard Hoekman and Jasper-Martijn Wauters for useful comments on previous drafts. Remaining errors are our own.

${ }^{1}$ Article 21.3 of the SCM Agreement reads, in relevant part: “... any definitive countervailing duty shall be terminated on a date not later than five years from its imposition (or from the date of its most recent review under paragraph 2 if that review 
withdrawal of CVDs would have led to a recurrence of subsidization and injury. The USDOC calculated the amount of countervailable subsidy to be $0.54 \%$ ad valorem, inasmuch as two of the original five subsidy programs had been terminated between the time of the original investigation and that of the administrative review.

\section{Issues raised before the Panel}

The European Communities complained that the US review was inconsistent with US obligations under the SCM Agreement. In the view of the European Communities, the United States should have withdrawn the CVDs when they found that the amount of countervailable subsidy to be $0.54 \%$ ad valorem. The European Communities argued that Article 11.9 of the SCM Agreement provided support for its argument in this respect; Article 11.9 obliges WTO Members to terminate original subsidy investigations when the amount of subsidy is calculated to fall below a de minimis standard of $1 \%$ ad valorem. According to the European Communities, the same standard ought to apply to subsequent sunset reviews as well. Not only was US practice in violation of the SCM Agreement, argued the European Communities, but the US law, which prescribes a de minimis standard of $0.5 \%$ ad valorem for sunset reviews, was illegal as well. Thus, the European Communities claimed that the United States had violated both Article 21.3 and Article 32.5 of the SCM Agreement, the latter requiring that each Member take measures to ensure the conformity of its laws and procedures with the terms of the Agreement.

The European Communities further complained about the evidentiary standard set out in US law and applied in its sunset reviews. In its opinion, the standard used by the United States for automatic self-initiation of sunset reviews falls short of the requirements of Articles 21.3 and 10 of the SCM Agreement.

Finally, the European Communities complained that the United States had violated its obligations under Articles 21.4 and 12 of the SCM Agreement when it considered the likelihood of continuation or

has covered both subsidization and injury, or under this paragraph), unless the authorities determine, in a review initiated before that date on their own initiative or upon a duly substantiated request made by or on behalf of the domestic industry within a reasonable period of time prior to that date, that the expiry of the duty would be likely to lead to continuation or recurrence of subsidization and injury. The duty may remain in force pending the outcome of such a review." 
recurrence of subsidization in the event of removal of countervailing duties by not allowing ample opportunity for interested parties to present their views in the context of the sunset review.

\section{The Panel Decision}

The WTO Panel rejected the EC arguments that US evidentiary standards were inconsistent with Article 21.3 of the SCM Agreement, that US law concerning the obligation to determine the likelihood of continuation of recurrence of subsidization in sunset review is inconsistent with Article 21.3 of the SCM Agreement, and that the United States had violated its obligation under the SCM Agreement by failing to provide interested parties with an opportunity to present their views. Regarding the last of these findings, the Panel noted that the European Communities had not included the issue among its list of complaints when requesting the establishment of a panel, and thus the issue did not fall within its terms of reference per Article 6.2 of the Dispute Settlement Understanding.

On the other hand, the Panel found that the United States had violated its obligations under the SCM Agreement by not adhering to a de minimis standard of $1.0 \%$ in its sunset review. The Panel ruled that the United States had violated both Article 21.3 of the SCM Agreement in the specific instance under review, and also had violated Article 32.5 by failing to bring its laws into conformity with the terms of the Agreement.

Finally, the Panel found that the United States had failed to determine properly the likelihood of continuation or recurrence of subsidization in its sunset review and thus had acted in a manner inconsistent with Article 21.3. It should be emphasized that the Panel's finding in this respect concerns US practice and not the US law as such, which the Panel found to be consistent with the US obligations under the SCM Agreement.

\section{The Appeal and the Appellate Body Decision}

Both sides appealed aspects of the Panel decision, although the United States did not contest the Panel ruling that it had failed to determine properly the likelihood of continuation or recurrence of subsidization in this particular case. The United States appealed the Panel findings that a $1.0 \%$ de minimis standard applies to ad valorem subsidy rates in a sunset review. The European Communities contested the Panel finding that the evidentiary standards used by the United States in its sunset review are not inconsistent with its WTO obligations, and that the US laws concerning 
the procedures to be used in determining likelihood of continuation of recurrence of subsidization in sunset review are not inconsistent with the SCM.

In United States - Countervailing Duties on Certain Corrosion-Resistant Carbon Steel Flat Products from Germany (WTO Doc. WT/DS213/AB/R, henceforth Carbon Steel), the Appellate Body upheld all but one of the Panel's findings; it reversed only the finding that the United States had acted in a manner inconsistent with its obligations by failing to apply a de minimis standard $1 \%$ ad valorem in its sunset review of the case under dispute. According to the $\mathrm{AB}$, the SCM Agreement imposes no restriction on the size of a subsidy that can be subject to continued countervailing measures, provided the subsidies continue to cause or threaten to cause injury in the importing country.

Since the Panel had ruled that the United States had failed to determine properly the likelihood of continuation or recurrence of subsidization in the particular sunset review at issue in this case, and since this finding generated no appeal from the United States, the AB requested that the United States bring its measures in Carbon Steel into conformity with its WTO obligations.

\section{Discussion of the AB Decision}

\subsection{The function of sunset reviews}

In a report last year [see Grossman and Mavroidis (2003)], we discussed the role of countervailing duties in the global trading system. We concluded that

... the effect of a subsidy on aggregate welfare in another Member country is a priori ambiguous. Therefore, if the Members had intended the SCM Agreement to discourage actions that would inflict welfare losses on others, they would have directed the "test" for actionable subsidies toward identifying conditions where aggregate loss is most likely to occur. For example, an external welfare loss is more likely to occur when a government subsidizes firms that sell in an imperfectly competitive market. So the test for an actionable subsidy might have made reference to the competitive conditions of the subsidized industry. Similarly, a welfare loss is more likely when wages are sticky in the importing country than when they are flexible; so the Agreement might have made reference to the labor-market conditions there. The Agreement might also have allowed for countervailing measures in Member countries that export goods in competition with the 
subsidized good, inasmuch as these countries are quite likely to suffer welfare losses as a result of a foreign subsidy.

In fact, the SCM Agreement does not confine the use of CVDs to situations in which an importing country has established the presumption of a welfare loss. The Agreement makes no reference to labor-market conditions, to market structure, or even to consumer welfare. And the Agreement makes no allowance for countervailing measures in countries that export the subsidized good, where the presumption of welfare losses surely exists. ${ }^{2}$ Rather, countervailing measures are permitted only when there has been (or threatens to be) injury to a domestic industry in an importing country.

The observation that injury to import-competing interests provides the sole basis for countervailing action points to a different interpretation of the objective of the SCM Agreement. Evidently, the signatories meant to discourage certain policy actions that would harm competing producer interests in the importing country. This objective is understandable in the light of recent literature on the political economy of trade policy, which has emphasized that governments often set their trade policies with objectives other than the maximization of aggregate economic welfare in mind. The policies that are chosen typically reflect a compromise among competing constituent interests. Moreover, some interests - especially those that are relatively concentrated - receive more weight in the political process than others. Less concentrated groups are not so successful in the political arena, in part because they have difficulty in overcoming the free-rider problems that plague collective political action (Olson, 1965). Thus, governments often are induced by political pressures to give more weight to producer interests than to consumer welfare when making their decisions about trade policy.

(emphasis in the original)

The SCM Agreement provides for two means of terminating a countervailing duty (CVD). First, the imposition of a CVD might end following a selfinitiated or requested administrative review, as provided for in Article 21.2.

2 Although the Agreement recognizes the possibility of serious prejudice to the interests of another Member that may arise due to the displacement of exports of a like product to the market of the subsidizing Member or to a third-country market, it does not allow serious prejudice to exporting interests to be a basis for countervailing action. Rather, in such cases, the Agreement calls for consultations between the Member that is granting or maintaining a subsidy and the Complaining Member, followed by a panel review in the event that consultations do not result in a mutually agreed solution. Only after a report by a panel or Appellate Body has been adopted in which it is determined that a subsidy has resulted in adverse effects to the interests of another Member, and the subsidizing Member has failed to take appropriate steps to remove the adverse effects of the subsidy may the complaining Member take such countermeasures as have been authorized by the Dispute Settlement Body (see Articles 7.8 and 7.9 of the SCM Agreement). 
Second, a CVD might be allowed to lapse after five years or be terminated following a sunset review conducted at that time. Article 21.3 stipulates that

any definitive countervailing duty shall be terminated on a date not later than five years from its imposition... unless the authorities determine ... that the expiry of the duty would be likely to lead to continuation or recurrence of subsidization and injury

(emphasis added)

Thus, the Agreement incorporates a rebuttable presumption that protection will no longer be needed after a period of five years. In order to continue a CVD beyond that time, the competent authorities must conduct a review in which they find that continued application of the duty is necessary to prevent a recurrence of the injurious effects of the subsidy.

Our analysis of the role of CVDs applies to sunset reviews just as it does to the initial investigation inasmuch as the injury standard is the same in both cases. We find support for this claim, for example, in footnote 45 of the SCM Agreement, which reads:

Under this Agreement the term 'injury' shall, unless otherwise specified, be taken to mean material injury to domestic industry, threat of material injury to a domestic industry or material retardation of the establishment of such an industry and shall be interpreted in accordance with the provisions of this Article

(emphasis added)

Since Article 21.3 of the SCM Agreement concerning sunset reviews does not specify otherwise, we must conclude that the Members intended the same standards to apply in such reviews.

\subsection{De minimis standards in sunset reviews}

\subsubsection{The Panel's reasoning}

Whereas the SCM Agreement provides for a de minimis threshold of 1\% ad valorem in all original investigations of countervailable subsidies, ${ }^{3}$ it makes no explicit reference to any such standard in the body of Article 21, which provides for the sunset reviews. The US trade law respects the

${ }^{3}$ Article 11.9 states that "... There shall be immediate termination [of an initial investigation] in cases where the amount of a subsidy is de minimis, or where the volume of subsidized imports, actual or potential, is negligible. For the purpose of this paragraph, the amount of the subsidy shall be considered to be de minimis if the subsidy is less than 1 per cent ad valorem." 
stipulated $1 \%$ threshold for original subsidy investigations, but provides for a lower $0.5 \%$ threshold for all subsequent reviews.

The Panel nonetheless found that the United States had acted in a manner inconsistent with its obligations under the SCM Agreement by employing a de minimis threshold of $0.5 \%$ ad valorem in its sunset review of a CVD on certain corrosion-resistant carbon steel products from Germany. The Panel ruled that the WTO Members intended the $1 \%$ threshold to apply not only in original investigations, but also in all subsequent reviews. According to the Panel, the Members could not have meant for there to be two different standards at the different points in time. Rather, the Panel interpreted the silence in Article 21.3 of the SCM Agreement as tacit acceptance of the standard laid out in the earlier Article 11.9.

The Panel supported its interpretation by asserting that the SCM Agreement aims, inter alia, to counteract injurious subsidies. ${ }^{4}$ Since the Members had decided to set a de minimis standard of $1.0 \%$ ad valorem for the original investigation, they must have believed that subsidies at less than this rate could not cause injury sufficient to warrant countervailing measures. Arguably, a subsidy at less than $1 \%$ ad valorem also could not cause such injury at a later stage. ${ }^{5}$ The Panel concluded that, since only subsidies that are causing injury can be subject to CVDs, de minimis subsidies that cannot cause sufficient injury (as defined in Article 11.9) cannot be deemed countervailable.

\subsubsection{The $\mathrm{AB}$ reversal: silence must mean something}

The $\mathrm{AB}$ rejected the Panel's reasoning on the issue of de minimis thresholds in sunset reviews. The $\mathrm{AB}$ advanced several arguments to support its position.

First, the $\mathrm{AB}$ argued that the Agreement's silence in Article 21 on the issue of de minimis thresholds for sunset reviews must have meaning. In

${ }^{4}$ In support of this point, the Panel pointed to a negotiating document prepared by the WTO Secretariat during the Uruguay Round multilateral trade negotiations. This document offered two rationales for the introduction of de minimis standards, one of which was to ensure that CVDs would counteract only injurious subsidies; see para. 77 of Carbon Steel.

5 The preparatory work for the SCM Agreement suggests that the de minimis standard was incorporated into the agreement to preclude the use of its provisions as a form of harassment. The signatories felt that Members should not be allowed to proceed with an investigation in situations where, arguably, the injurious effects of a subsidy could not have been great in view of the low rate of subsidization. It is impossible to discern from the preparatory work, however, the basis for setting the threshold at $1 \%$ rather than at some other level. 
particular, the $\mathrm{AB}$ notes that cross-referencing would have been an option, and indeed has been used quite frequently in the SCM Agreement. The AB interprets the absence of such cross-referencing to mean that the Members did not intend the threshold requirements incorporated into Article 11.9 to apply also to the reviews discussed in Article 21.

Second, the $\mathrm{AB}$ dismissed the relevance of the negotiating document cited by the Panel inasmuch as the documents list the counteracting of injurious subsidies as only one of two rationales for the introduction of de minimis thresholds in the original investigation. The $\mathrm{AB}$ notes in para. 78 of its report on Carbon Steel that there is no reason for the interpreter of Article 21 to rely on this particular rationale for de minimis thresholds while dismissing the other. The $A B$ further argues (in paras. 79-81) that, as a matter of general matter, subsidy and injury are two distinct concepts in the SCM Agreement and the latter is not defined with reference to any minimum ad valorem subsidy rate. The Agreement also distinguishes the original investigation and subsequent reviews as two distinct processes with their own rules and procedures. The $\mathrm{AB}$ sees no a priori reason why the requirements for invoking countervailing duties should be the same in the two processes.

The $\mathrm{AB}$ concludes that the US law, which provides for a de minimis threshold of $0.5 \%$ ad valorem for a subsidy to be countervailable following a sunset review, is not inconsistent with US obligations under Article 21.3 of the SCM Agreement.

\subsubsection{In support of the $\mathrm{AB}$ ruling}

There are additional arguments that support the $\mathrm{AB}$ ruling on the use of de minimis thresholds in sunset reviews. First, the maxim of in dubio pro mitius favors the Appellate Body's interpretation of the SCM Agreement. According to this maxim of public international law, the international judge, because of his/her function (as an agent, not a principal) cannot presume a transfer of sovereignty when none is present. The interpreter, when in doubt (in dubio), must interpret an international agreement narrowly; that is, assuming that sovereignty remains with the states rather than assuming that it has been transferred to the international regime (pro mitius). Legislative silence presents at least genuine doubt as to whether sovereignty has been transferred. The maxim of in dubio pro mitius reflects an intellectually coherent proposition in the light of the frequent challenges of the purview of the international regime that are brought before international courts. And whereas an ill-advised judgment by a domestic court in a national context can readily be overturned via 
subsequent legislative action, a poor decision by an adjudicating body of the WTO will require, before it can be corrected, a consensus among 146 Member countries. Since agency costs associated with poor judicial decisions are especially high in an international context, it behooves an international court to let sovereignty remain with the Member countries whenever a legitimate doubt exists.

Second, the interpretation favored by the $\mathrm{AB}$ may well be consistent with the overall objectives of the SCM Agreement as applied to the issue of de minimis thresholds. As we explained in Grossman and Mavroidis (2003) and rehearsed in Section 5.1 above, CVDs play an important role in the international trading system not only to offset injury, but also to discourage countries from implementing subsidies that might cause harm to a domestic industry in an importing country in the first place. Subsidies are not per se illegal in the international trading regime. Rather, countervailing duties are permitted to ensure that governments have adequate incentive to consider the externalities that their national policies impose on their trading partners. The longer lasting the CVDs, the greater the disincentive to a government to implement subsidies that do harm to their trade partners. It is at least plausible that the WTO Members intended to allow countervailing measures against small subsidies as a way to discourage governments from keeping subsidies in place longer than is necessary. Since the Agreement is silent on the issue of whether de minimis thresholds ought to apply in sunset reviews, it is enough that a plausible case can be made that no such thresholds were intended to justify the overturning of the Panel's ruling by the AB.

Finally, the wording of footnote 52 (to Article 21.3 of the SCM Agreement) seems to lend support to the Appellate Body's approach. It provides that

[w] hen the amount of the countervailing duty is assessed on a retrospective basis, a finding in the most recent assessment proceeding that no duty is to be levied shall not by itself require the authorities to terminate the definitive duty.

If a finding that no duty should be levied does not in and of itself require that the authorities terminate the duties imposed, then by inference a finding of de minimis subsidization should lead to the same result. ${ }^{6}$

${ }^{6}$ This point was made to us orally by Jasper-Martijn Wauters. We should probably note that our comments here assume the legal text as a constraint on the Appellate Body's decision. In fact, we can see some good arguments in favor of the Panel's position (that was overturned by the $\mathrm{AB}$ ) that a subsidy scheme, when below a de minimis level defined in the SCM Agreement, should be regarded as non-injurious during both the original investigation and subsequent reviews. However, the language of Article 21.3 of the SCM Agreement does not lend sufficient support to these arguments. 


\subsection{Evidentiary standards in self-initiated sunset reviews}

The US law provides for automatic self-initiation of sunset reviews 30 days before the fifth anniversary of the original imposition of a CVD, regardless of whether the USDOC is in possession of any relevant evidence or not. The European Communities disputed the consistency of the US legislation with the terms of the SCM Agreement. According to the European Communities, the evidentiary standards stipulated in Article 11.6 of the SCM Agreement as requirements before an investigatory authority can itself initiate an original investigation of a foreign subsidy ought to apply as well to the self-initiation by such authorities of a sunset review. Specifically, the European Communities claimed that the United States, if it wishes to self-initiate a sunset review, should possess the same level of information as would be required in a "duly substantiated request" for a review by the domestic industry. The Panel rejected the EC claims, ruling that Article 21.3 of the SCM Agreement dictates no specific evidentiary standards for the self-initiation of sunset reviews.

The $\mathrm{AB}$ upheld the Panel's ruling on appeal. It pointed to the wording of Article 21.3, which mandates the elimination of CVDs after five years "unless the authorities determine, in a review initiated before that date on their own initiative or upon a duly substantiated request made by or on behalf of the domestic industry." The $\mathrm{AB}$ argued that the adjective "duly substantiated" modifies only the "request made by or on behalf of the domestic industry" and not the alternative method described for initiating a sunset review, namely self-initiation by the investigating authorities. Again, the $\mathrm{AB}$ interpreted silence to mean that the provision places no limitation on the manner in which the Member country may take the indicated action.

In our view, the most persuasive argument in support of the Panel's decision was not mentioned in the report on Carbon Steel. When it comes to the original investigation, Articles 11.2 and 11.6 of the SCM Agreement establish a balance between investigations initiated following a request by the domestic industry and self-initiated investigations. Whereas an industry petition can generate a subsidy investigation whenever certain substantive requirements are satisfied, government-initiated investigations are reserved for exceptional cases. On this point, Article 11.6 of the SCM Agreement states that

If, in special circumstances, the authorities concerned decide to initiate an investigation without having received a written application by or on behalf 
of a domestic industry for the initiation of such investigation, they shall proceed only if they have sufficient evidence of the existence of a subsidy, injury and causal link, as described in paragraph 2, to justify the initiation of an investigation

Article 21.3 of the SCM Agreement does not, however, treat self-initiated sunset reviews as exceptional procedures. A coherent argument could be advanced in favor of a parallelism between the two provisions: absent an abiding interest by the domestic industry (the entity which has the incentive to request protection) an investigating authority should neither initiate an investigation nor review duties to evaluate whether they are still needed, except in unusual circumstances. In other words, if the domestic industry fails to take the initiative to request the application of a CVD or its continuation, the competent authorities should take this as a signal that trade protection would not be especially beneficial to the industry. In such circumstances, no CVD should be applied or continued, considering that such protection confers negative externalities on a Member's trading partners.

But whereas Article 11.6 of the SCM Agreement treats the initiation of an investigation by the government authorities as an exceptional event, Article 21.3 of the SCM Agreement does not do so. This discrepancy provides a rationale for a looser evidentiary standard during the review stage. The degree of leniency that should be allowed relative to the requirements of Article 11.2 of the SCM Agreement is a matter that must be addressed on a case-by-case basis. The $\mathrm{AB}$ chose to interpret silence literally as an absence of any requirement whatsoever, so that competent authorities may choose to conduct sunset reviews even when they are in possession of no evidence to suggest that the CVD is still needed. Their interpretation certainly cannot be rejected based on a contextual reading of the text of Article 21.3 of the SCM Agreement.

\subsection{The likelihood of continuation or recurrence of subsidization}

The European Communities further argued that US law and practice essentially prohibit the USDOC from examining changes to the subsidy programs that may occur subsequent to an initial investigation. Several of the EC claims were rejected by the Panel and the AB, because they were not properly raised during the dispute process. The $\mathrm{AB}$ also rejected the appeal by the European Communities that faulted the Panel for failing to condemn a "consistent practice" on the part of the United States as 
regards changes to subsidy programs. The $A B$ noted that, in making this assertion, the European Communities had relied primarily on the US conduct in the case under review. Such US actions, whatever they may have been, could not amount to a "consistent practice."

The European Communities had argued that US trade law [Section 752(b)(1) of the US Tariff Act] does not allow the USDOC to consider changes in subsidy programs when determining the likelihood of continuation or recurrence of subsidization. The Panel relied on the language of the law to conclude that it did not, in fact, mandate behavior inconsistent with Article 21.3 of the SCM Agreement. The AB upheld this ruling, and we concur.

\subsection{The opportunity to present evidence in sunset reviews}

The European Communities complained that, during the Panel proceedings, the United States had violated its obligations under Article 12 of the SCM Agreement by not providing interested parties with ample opportunity to present their views. The United States objected to this claim, arguing that it fell outside the Panel's terms of the reference inasmuch as the issue had not been raised at the time that the European Communities invoked the dispute resolution process. The United States referred to Article 6.2 of the Dispute Settlement Understanding (DSU) for support on this issue.

In reviewing the $\mathrm{EC}$ request for the establishment of a panel, the Panel found only a reference to an objection to "certain aspects of the review procedure." The Panel did not find this reference to be sufficiently specific to identify the issue at hand. In the case law on the issue of the Panel's terms of reference, the WTO adjudicating bodies have consistently interpreted Article 6.2 of the DSU as requiring complainants to identify the factual situation about which they complain and the legal provision that allegedly has been violated in the document submitted to request a panel. Accordingly, the Panel ruled in favor of the United States on this issue.

On appeal, the $\mathrm{AB}$ upheld the Panel ruling, on the grounds that the EC request for establishment of a panel had failed to identify Article 12 of the SCM Agreement as the basis for its contention that its rights had been violated. We agree with the Panel and the $\mathrm{AB}$ on this finding, noting that were Article 6.2 of the DSU to be interpreted otherwise, complainants would be able to surprise defendants with new allegations at all the stages of the dispute settlement proceedings. 


\section{Conclusions}

We concur with the AB findings about the non-applicability of de minimis thresholds in sunset review and have developed some additional arguments to support its ruling. We also concur with the $\mathrm{AB}$ findings on evidentiary standards during reviews. Both of our conclusions are predicated on our understanding of the function of (or, the objectives pursued by) the SCM Agreement as currently drafted.

This does not mean, however, that we agree with the current drafting of the SCM Agreement on the issues under review. In fact, we see good arguments in favor of a re-drafting of Article 21.3 of the SCM Agreement in two respects.

(a) The Agreement should make clear that, the absence of de minimis standards notwithstanding, if the level of subsidization is found to have fallen over time, then the size of the CVD should shrink as well after the sunset review (since the purpose of a CVD is to offset the "distortion" caused by the subsidy and not to (over-)compensate the affected domestic industry). As Article 21.3 of the SCM Agreement now stands, it is unclear whether, in case the level of subsidization changes over time, the size of the countervailing duty must change as well.

(b) The evidentiary standards during the sunset review stage should be changed to restore parallelism with the standards used during original investigations initiated by industry petition and those initiated by the investigating authority. A lack of interest by the domestic industry in continuing a CVD action should be used as a signal that no further protection is warranted. As the text now stands, it is difficult to advance a convincing legal argument in favor of such parallelism.

\section{Post Scriptum}

We note that, in a subsequent dispute concerning a review of antidumping duties, the $\mathrm{AB}$ reached a conclusion that might be regarded as being at odds with the decision discussed here. Like the SCM Agreement, the $A D$ Agreement incorporates a de minimis threshold for the dumping margin at the investigatory stage leading to the original imposition of duties, but contains no explicit reference to any de minimis standards that must be applied during a sunset review. In its report on United States - Sunset 
Review Of Anti-dumping Duties On Corrosion-resistant Carbon Steel Flat Products From Japan (WTO Doc. WT/DS244/AB/R of 15 December 2003) the $\mathrm{AB}$ reaffirmed in $\S \S 124-127$ its view that a competent authority is not obliged by the agreement to calculate precise dumping margins during a review of antidumping duties. It went on, however, to specify that in case a WTO Member does choose to calculate margins in such a review, it must do so in accordance with the procedures stipulated in Article 2 of the $\mathrm{AD}$. Article 2 regulates the procedures for calculating the dumping margin during an original investigation and constitutes one of the three prerequisites for the lawful imposition of antidumping duties under Article 1 of the AD. But Article 1 further stipulates that Article 5 must govern the conduct of an investigation, and Article 5.8 contains the de minimis rule that obliges WTO Members to discontinue any investigation if they find the dumping margin to be below $2 \%$. Consequently, any definition of the dumping margin that accords with Article 2 of the $\mathrm{AD}$ must obey the de minimis threshold reflected in Article 5.8. In short, it is possible to interpret the $\mathrm{AB}$ ruling in the $\mathrm{AD}$ case as requiring the de minimis standard for an initial investigation also to be observed in any sunset review that involves the calculation of dumping margins.

\section{References}

Grossman, Gene M. and Petros C. Mavroidis. 2003. Here Today, Gone Tomorrow? Privatization and the Injury Caused by Non-Recurring Subsidies. A Discussion of the Appellate Body Report on United States - Imposition of Countervailing Duties on Certain Hot-Rolled Lead and Bismuth Carbon Steel Products Originating in the United Kingdom in H. Horn and P. C. Mavroidis, eds., The WTO Case Law of 2001. Cambridge: Cambridge University Press. 